\title{
A new species of the genus Liljeborgia Spence Bate, 1862 (Crustacea: Amphipoda: Liljeborgiidae) associated with the burrows of the spoon worm Urechis unicinctus in the Sea of Japan
}

\author{
Ivan MARIN \\ A.N. Severtsov Institute of Ecology and Evolution of RAS, Moscow, Russia. \\ Email: coralliodecapoda@mail.ru,vanomarin@yahoo.com \\ urn:1sid:zoobank.org:author:B26ADAA5-5DBE-42B3-9784-3BC362540034
}

\begin{abstract}
A new symbiotic species of liljeborgiid amphipods, Liljeborgia associata sp. nov., is described from the burrows of the spoon worm Urechis unicinctus (Drasche, 1880) (Annelida: Polychaeta: Echiura: Urechidae) in the southern part of Peter the Great Bay and Posjeta Bay in the Sea of Japan. The new species is mostly similar and probably related to Liljeborgia geminata Barnard, 1969, known from the Californian coasts of the USA, and Liljeborgia serratoides Tzvetkova, 1967, described from Posjeta Bay in the Sea of Japan, but can be clearly distinguished from all congeners by morphological features of mouthparts, appendages and telson. The new species is only the fourth in the family Liljeborgiidae to be described from the Russian coast of the northwestern Pacific and the first in association with spoon worms (Echiura).
\end{abstract}

Keywords. Diversity, association, northwestern Pacific, boreal, barcoding.

Marin I. 2020. A new species of the genus Liljeborgia Spence Bate, 1862 (Crustacea: Amphipoda: Liljeborgiidae) associated with the burrows of the spoon worm Urechis unicinctus in the Sea of Japan. European Journal of Taxonomy 613: 1-19. https://doi.org/10.5852/ejt.2020.613

\section{Introduction}

Representatives of the family Liljeborgiidae (Crustacea: Amphipoda) are relatively rare in the higher latitudes of the North Pacific. Only three genera, Liljeborgia Spence Bate, 1862, Idunella G.O. Sars, 1894 (= Listriella J.L. Barnard, 1959) and Sextonia Chevreux, 1920, are known from the area. About $10+$ species of the family are known from the NE Pacific (eastern coasts of the Bering Sea; Pacific coasts of North America), including four described species of the genus Liljeborgia: Liljeborgia cota Barnard, 1962 known from the Gulf of Alaska to the northern Baja California, Mexico, at a depth of 366-2000 m; L. geminata Barnard, 1969 (L. kinahani Bate, 1862 is considered as a junior synonym), described from Goleta to the northern Baja California, at a depth of 3-70 m; L. marcinabrio Barnard, 1979, known from Bahia de Los Angeles, Gulf of California, at a depth of $46 \mathrm{~m}$; and L. pallida Bate, 1857, having a wide area of distribution from NE Atlantic to the Central Californian coasts, at a depth of 40-611 m (Barnard 1959; Barnard \& Karaman 1991; d'Udekem d'Acoz 2010; Cadien 2015). Moreover, two undescribed species are also presented in the NE Pacific: one free-living, deep-water species and one commensal 
with Pagurus hemphilli (J.E.Benedict, 1892) (Crustacea: Decapoda: Paguridae), living along the shores of Central California (Cadien 2015).

The diversity of the family along the coasts of the NW Pacific (western coasts of the Bering Sea; Pacific coasts of Russia and Japan; Sea of Okhotsk; northern parts of the Sea of Japan and the Yellow Sea) is less studied and is obviously underestimated. Only three species of the family have been reported from Russian waters: Liljeborgia serratoides Tzvetkova, 1967 was described from the shallow waters of Posjeta Bay in the Sea of Japan (Tzvetkova 1967), Sextonia caecus Labay, 2017 was recently described from the Sea of Okhotsk, at a depth of 109-309 m (Labay 2017) and Gurjanova (1951) reported Northern Atlantic and Arctic Lilljeborgia cf. fissicornis (M. Sars, 1858) from the Bering Sea, representing the only known record of the species from the NW Pacific (see d'Udekem d'Acoz \& Vader 2009). The geographically closest species of the family Liljeborgiidae to the aforementioned species are known from the Seto Inland Sea in southern Japan, where Liljeborgia japonica Nagata, 1965 and L. serrata Nagata, 1965, Idunella chilkensis Chilton, 1921 and I. curvidactyla Nagata, 1965 were described by Nagata (1965), and the Yellow Sea, where L. hwanghaensis Kim \& Kim, 1990 and L. sinica Ren, 1992 are also known (Kim \& Kim 1990; Ren 1992, 2007; Ishimaru 1994).

A variety of symbiotic communities associated with soft-bottom deep-burrowing invertebrates were investigated in the Peter the Great Bay and Posjeta Bay in the Sea of Japan. The sampling of infaunal animals and symbiotic assemblage was carried out using a bait suction pump (yabby pump), which allowed us to study the diversity of burrowing crustaceans and their associates in Russian waters (e.g., Marin 2010, 2015, 2016, 2018a, 2018b; Marin et al. 2011, 2013; Marin \& Kornienko 2014) with the description of several new crustacean (Marin 2013, 2017) and even a new phoronid species (Temereva \& Chichvarkhin 2017). Numerous specimens of Liljeborgia sp. were also collected from the burrows of the spoon worm Urechis unicinctus (Drasche, 1880) (Annelida: Polychaeta: Echiura: Urechidae). Previously, this species was identified as L. serratoides/geminata in accordance with its similar morphology and distinctive coloration, however, the presence of several specific morphological features has allowed its separation into a new species described herewithin.

\section{Material and methods}

\section{Specimen sampling and imaging}

Sampling was carried out in the estuary of Volchanka River in Vostok Bay near the scientific station

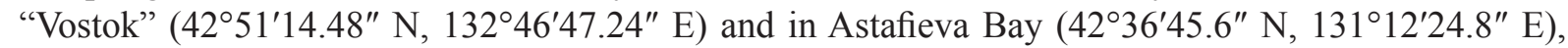
both within Peter the Great Bay, as well as Troitza Bay $\left(42^{\circ} 38^{\prime} 60.0^{\prime \prime} \mathrm{N}, 131^{\circ} 07^{\prime} 27.8^{\prime \prime}\right.$ E) located within Posjeta Bay in Sea of Japan (see Fig. 1). These bays are well known by large populations of the common spoon worm U. unicinctus and other burrowing animals. The hosts and symbiotic community were collected using a bait suction pump (yabby pump), which is actively used in the sampling of deep burrowing animals (e.g., Eleftheriou \& McIntyre 2005). Unfortunately, in our study it was not possible to measure the length or volume of the host's burrows. The collected specimens were photographed alive in situ using a Canon G16 digital camera and then fixed with $90 \%$ ethanol solution. The drawings were made using camera a lucida attached to an Olympus SZX10 stereo microscope.

\section{Molecular study}

To study the molecular genetic diversity, a fragment of the mitochondrial gene coding for cytochrome c oxidase subunit I (COI mtDNA) gene marker was amplified, sequenced and compared. Two female specimens (LEMMI) from Vostok Bay were used for the moleculargenetic examination. Total genomic DNA was extracted from abdominal and pereiopod muscle tissue using the innuPREP DNA Micro Kit (AnalitikJena, Germany) following the manufacturer's protocol. The COI gene marker was amplified with the help of primers «m13polylco» 
(TGTAAAACGACGGCCAGTGAYTATWTTCAACAAATCATAAAGATATTGG) and «m13polyhco» (CAGGAAACAGCTATGACTAMACTTCWGGGTGACCAAARAATCA) (Carr et al. 2011); 16S with thehelpof+16SA('CGCCTGTTTATCAAAAACAT')and-16SH('CCGGTCTGAACTCAGATCACG'); $28 \mathrm{~S}$ with the help of $+\mathrm{C} 1$ ('ACCCGCTGAATTTAAGCAT') and -D2 ('TCCGTGTTTCAAGACGG'). PCR products were performed on amplificator T100 (Bio-Rad, USA) under the following conditions: initial denaturation at $96^{\circ} \mathrm{C}$ for $1.5 \mathrm{~min}$ followed by 42 cycles of $95^{\circ} \mathrm{C}$ for $2 \mathrm{~min}, 49^{\circ} \mathrm{C}$ for 35 seconds, and $72^{\circ} \mathrm{C}$ for $1.5 \mathrm{~min}$, followed by chain extension at $72^{\circ} \mathrm{C}$ for $7 \mathrm{~min}$. The volume of $10 \mu \mathrm{L}$ of reaction

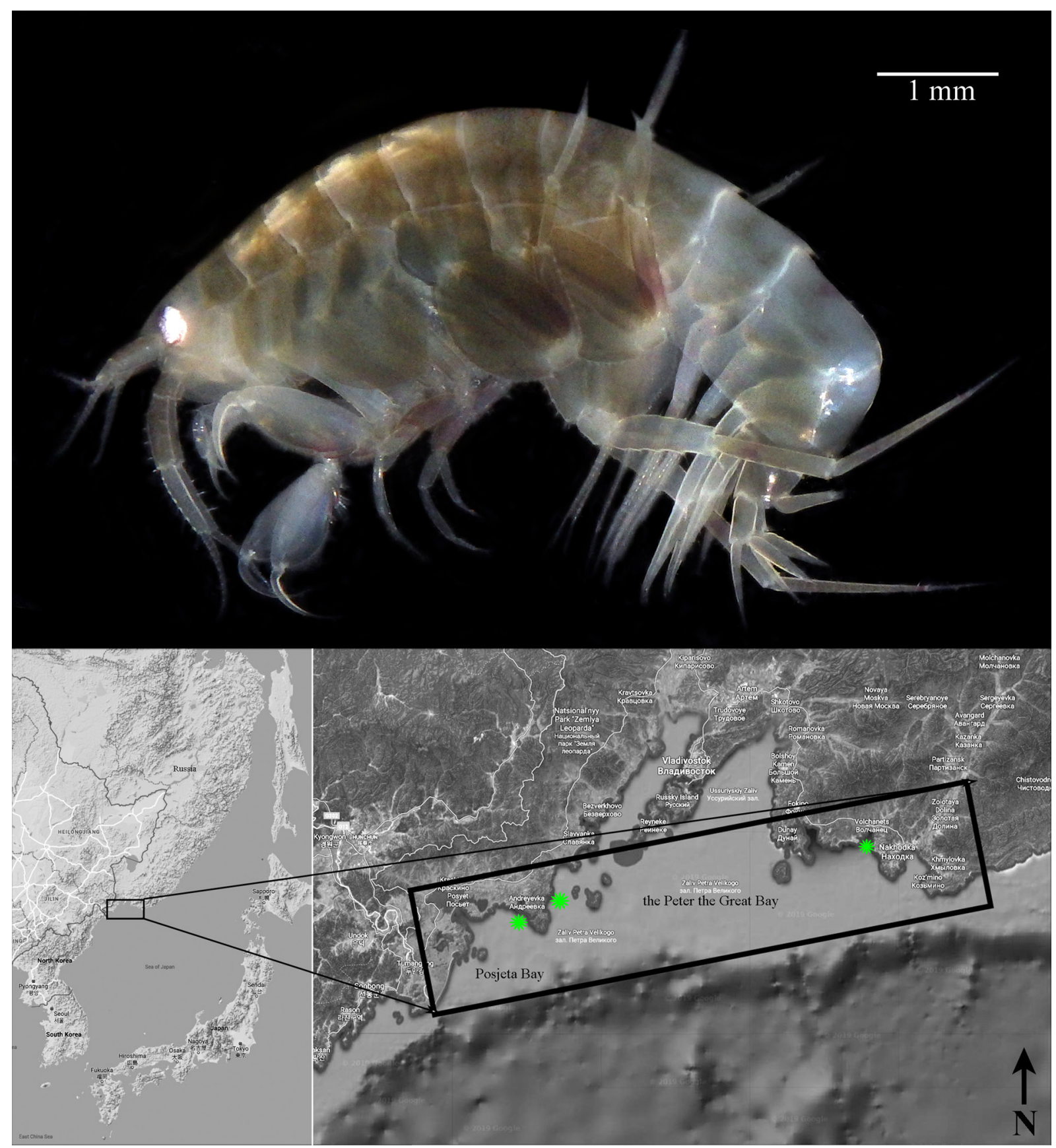

Fig. 1. Habitus of live female specimen of Liljeborgia associata sp. nov. from Vostok Bay of the Sea of Japan with geographical indication of the collection sites in the Peter the Great Bay and Posjeta Bay of the Sea of Japan. 
mixture contained $1 \mu \mathrm{L}$ of total DNA, $2 \mu \mathrm{L}$ of $5 \times$ PCR mix (Dialat, Russia) and $1 \mu \mathrm{L}$ of each primer. The amplification products were separated by using gel electrophoresis of nucleic acids on a $1.5 \%$ agarose gel in $1 \times \mathrm{TBE}$, and then stained and visualized with $0.003 \% \mathrm{EtBr}$ using imaging UV software. DNA nucleotide sequences were determined using Genetic Analyzer ABI 3500 (Applied Biosystems, USA) and BigDye 3.1 (Applied Biosystems, USA) with direct and reverse primers. Unfortunately, the number of sequences of the representatives of the family Liljeborgiidae deposited in genetic databases is still very small. As the phylogenetic relations of studied species are out of our interest, the obtained DNA (COI mtDNA) data are presented in the paper without any analysis.

\section{Type material and morphological study}

The type material is deposited in the collection of Zoological Museum of Moscow State University, Moscow, Russia (ZMMU) and the Laboratory of Ecology and Evolution of Marine Invertebrates (LEMMI), A.N. Severtzov Institute of Ecology and Evolution, Russian Academy of Sciences, Moscow, Russia.

The body length ( $\mathrm{bl}, \mathrm{mm}$ ), defined as the dorsal length from distal margin of head to the posterior margin of telson without the length of uropod III and antennae, is used as a standard measurement.

The terminology and the general model of the description are used in the study after d'Udekem d'Acoz \& Vader (2009) and d'Udekem d'Acoz (2010).

\section{Abbreviations}

$\begin{array}{ll}A 1 & =\text { antenna } 1 \\ A 2 & =\text { antenna 2 } \\ \text { bl } & =\text { body length } \\ \text { Ep1-3 } & =\text { epimeral plates 1-3 } \\ \text { Gn1 } & =\text { gnathopod 1 } \\ G n 2 & =\text { gnathopod 2 } \\ M d & =\text { mandible } \\ M x 1 & =\text { maxilla 1 } \\ M x 2 & =\text { maxilla 2 } \\ M x p & =\text { maxilliped } \\ P 1-P 7 & =\text { pereiopods 1-7 } \\ U 1-U 3 & =\text { uropods 1-3 }\end{array}$

\section{Results}

Phylum Arthropoda von Siebold, 1848

Class Malacostraca Latreille, 1802

Order Decapoda Latreille, 1802

Family Liljeborgiidae Stebbing, 1899

Genus Liljeborgia Spence Bate, 1862

Liljeborgia associata sp. nov. urn:1sid:zoobank.org:act:CC2A771F-71B2-4EED-9C16-3EF17CD0655D

Figs $1-5$

\section{Diagnosis}

$A 1$ with stout articles 2 (about as long as wide) and 3 (about 1.5 times as long as wide), article 2 with dorsal projection produced into a rounded lobe; palp of $M d$ with long and slender articles, article 3 
almost equal to articles 1 and 2, about 5 times as long as wide; palp of $M x 1$ with broad shovel-shaped article 1; stout articles 3 and 2 of $A 2$, article 3 about as long as wide and article 2 about 3 times as long as wide; $P 1$ and $P 2$ with short and wide merus, about 3 times as long as wide; $P P 5-7$ with slender propodal segments, about 6, 7 and 10 times as long as wide, respectively; posterodorsal area of Pleonites 1 and 2 produced into 3 small teeth of which the median one is the longest; Urosomites 1 and 2 with wellmarked dorsal crest; Telson with long distal teeth, accompanied by 2 interdental long and slender spines.

\section{Etymology}

The species is named after its symbiotic lifestyle.

\section{Type material}

\section{Holotype}

PACIFIC OCEAN • + (bl $6.5 \mathrm{~mm}$ ); Sea of Japan, Primorye, Peter the Great Bay, Vostok Bay, in front of the scientific station "Vostok"; 42 $54^{\prime} 35.8^{\prime \prime} \mathrm{N}, 132^{\circ} 44^{\prime} 08.7^{\prime \prime} \mathrm{E}$; depth 1-1.5 m; 30-31 Jul. 2017; I. Marin leg.; shore in front of the laboratory, sandy-gravel bottom overgrown with sea grass; yabbypump; from burrows of spoon worm U. unicinctus; ZMMU Mb-1153.

\section{Paratypes}

PACIFIC OCEAN • 1 ${ }^{\lambda}$; same data as for holotype; ZMMU Mb-1154 • 1 \% ; same data as for holotype; GenBank: MN704855, MN704856; ZMMU Mb-1155.

\section{Additional material}

PACIFIC OCEAN • 8 q $q, 1$ ; ; same data as for holotype; LEMMI $\bullet 5$ $q q$; Sea of Japan, Primorye, Posjeta Bay, Troitza Bay; 42³8'60.0" N, 13107'27.8" E; depth 1-1.5 m; Jul. 2019; I. Marin leg.; muddy sand; inside burrow of spoon worm U. unicinctus; yabby-pump; LEMMI - 1 \%; Peter the Great Bay,

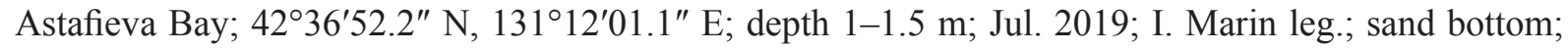
inside burrow of spoon worm U. unicinctus; yabby-pump; LEMMI.

\section{Description}

HeAd (Fig. 2c). Rostrum turned downward, distally acute; eye large (Fig. 1), with well-developed ommatidia, eye brightly white in alive specimens (Fig. 1).

Antenna 1 (Fig. 2d). Article 3 stout, about 1.5 times as long as wide; article 2 about as long as wide, with dorsal projection produced into a rounded lobe; major flagellum with 15-17 articles; accessory flagellum with 10-11 articles.

Antenna 2 (Fig. 2e). Article 3 about as long as wide, unarmed; article 2 about 3 times as long as wide, with 4 small dorsal spines, with 1 long distodorsal and 2 long simple distoventral spines, with simple setae ventrally; article 1 about 4-4.5 times as long as wide, with small dorsal spines, with 1 distoventral long spine, unarmed ventrally; flagellum with 13-15 articles.

LABrum (Fig. 2a). Upper lip with labrum broader than long and smaller than epistome, apical margin sinuous.

EpISTOME (Fig. 2b). With rounded lobes, protruding in lateral view, armed with small setae dorsally.

MANDIBLE (Fig. 2f). Lacinia mobilis large, anterior margin armed with 5 small strong teeth; palp consists of 3 long slender articles, similar in size, covered with long simple setae, article 1 almost equal to article 2, about 5-6 times as long as wide; article 2 about 5-6 times as long as wide; article 3 almost equal to articles 1 and 2, about 5 times as long as wide. 


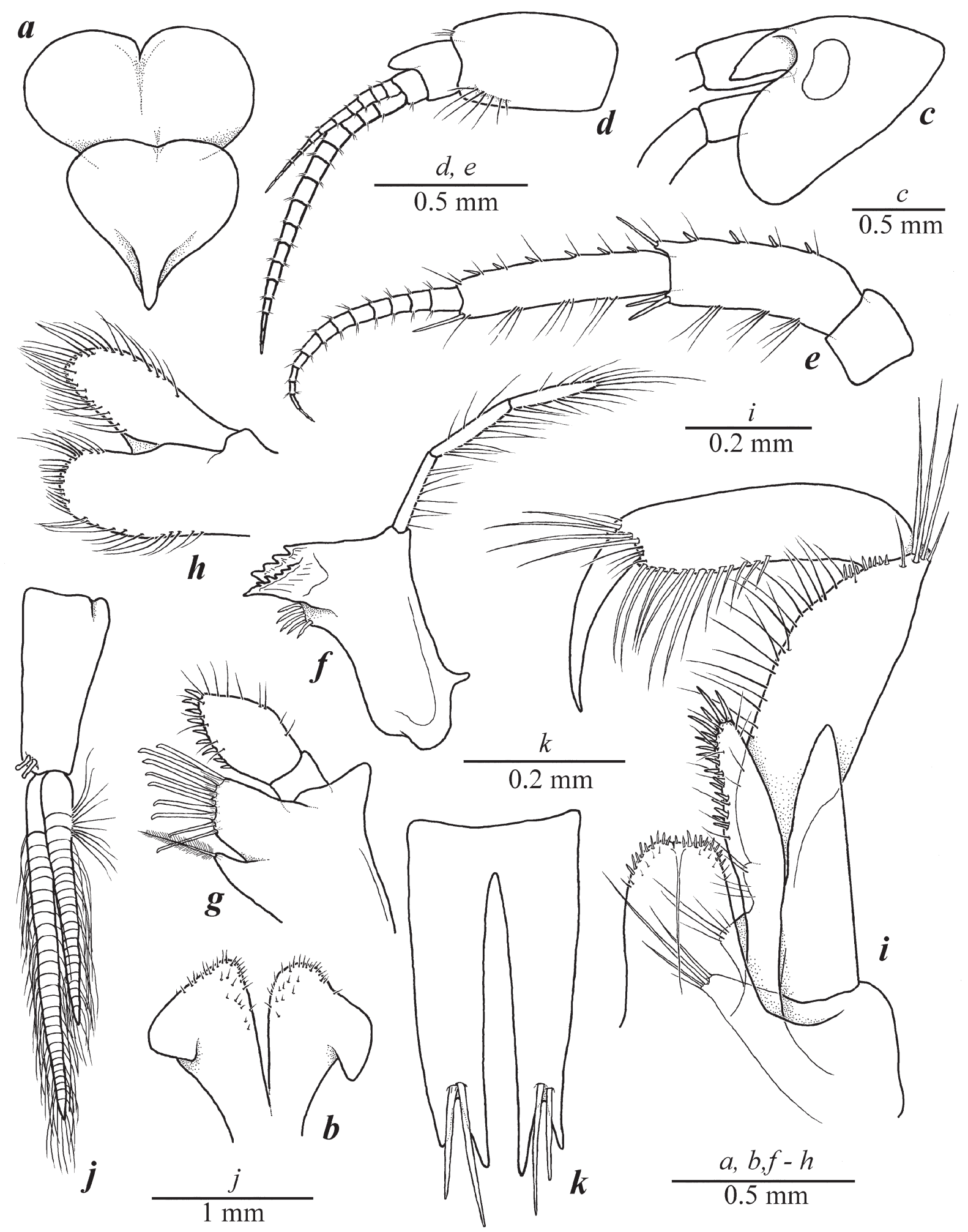

Fig. 2. Liljeborgia associata sp. nov., female (LEMMI) from Vostok Bay of the Sea of Japan. a. Upper lip. b. Lower lip. c. Head. d. Antenna 1. e. Antenna 2. f. Mandible. g. Maxilla 1. h. Maxilla 2. i. Maxilliped. j. Pleopod 1. k. Telson. 
MaXilla 1 (Fig. 2g). Outer plate with 8 large slender spines, ventrally denticulated; inner plate with a single long plumose seta; palp consists of 4 articles, article 1 shovel-shaped, with broad median part, about 1.5-2 times as long as wide, with 8-9 sharp robust spines along anterior margin, and simple small setae along dorsal margin.

MAXILLA 2 (Fig. 2h). Inner and outer plates distally rounded, robust, covered with numerous long simple setae along anterior and lateral margins.

MAXILLIPED (Fig. 2i). Palp consists of 4 articles: article 1 of palp unarmed, article 2 with a cluster of long setae distodorsally, small robust setae distally and long simple setae along the inner margin, outer margin unarmed; article 3 with a cluster of long simple setae along anterior border and distal part of inner margin, outer margin unarmed, article 4 (dactylus) slender, curved, about 0.8 times as long as article 3, unarmed; outer plate with 13-15 robust spines along medial border (distal spines are narrow and rather long); inner plate covered with small setae along anterior margin.

GNATHOPOD 1 (Fig. 3a). Coxa trapezoidal, with anterior medial setae only, posterior border weakly concave; basis slender, about 6-7 times as long as wide, with ventral projection in proximal part, with long simple setae; ischium about as long as wide, with long simple setae along distoventral border; merus about 1.5 times as long as wide, sharping distoventrally, with several groups of setae along ventral margin; carpus slender, with blunt distoventral process, reaching $1 / 3$ of palm length, not reaching propodal group of strong spines, armed with several groups of setae; propodus about twice as long as wide both in male and females (Fig. 3b), with convex ventral margin, armed with small simple setae along almost all its length, with a depression and 3 long simple setae in proximal part level with end of dactylus, dorsal margin straight and unarmed; dactylus with 5-7 triangular teeth.

GNATHOPOD 2 (Fig. 3c). Very similar to $G n 1$ in shape and slightly larger in size; coxa triangulo-elliptic; basis slender, about 6 times as long as wide, with long simple setae; ischium about as long as wide, with long simple setae along distoventral border; merus about 1.5 times as long as wide, sharpening distoventrally, with several groups of setae along ventral margin; carpus slender, with blunt distoventral process, reaching $1 / 4$ of palm length, not quite reaching propodal group of strong spines, armed with several groups of setae; propodus about 2 times as long as wide in both male (Fig. 5a) and females (Fig. 3d), dorsal margin straight and unarmed, with convex ventral margin, armed with small simple setae along almost entire length, with a depression and 3 long simple setae in proximal part level with end of dactylus; dactylus with 10-11 triangular teeth.

Pereiopod 3 (Fig. 4a). Coxa elliptic and narrow; basis slender, about 8-9 times as long as wide, with straight margins, covered with long simple setae; ischium about as long as wide, with long simple setae along distoventral border; merus broad, about 3 times as long as wide, slightly longer than carpus and equal to propodus, dorsal margin produced forward, with long simple setae along dorsal and ventral margins; carpus about 3 times as long as wide, with straight margins, unarmed dorsally and with simple long setae along ventral margin; propodus about 4-4.5 times as long as wide, slightly curved, unarmed dorsally and ventrally, with several long simple setae at distodorsal angle; dactylus of normal length, slender, weakly curved, slightly shorter than propodus and equal to carpus in length.

PeREIOPOD 4 (Fig. 4b). Coxa wide, with parallel anterior and posterior border, ventral border with 3 wellmarked serrations; basis slender, about 7-7.5 times as long as wide, with straight margins, covered with long simple setae; ischium about as long as wide, with long simple setae along distoventral border; merus broad, about 3 times as long as wide, longer than carpus and slightly shorter than propodus, dorsal margin produced forward, with long simple setae along dorsal and ventral margins; carpus about 2.5-3 times as long as wide, with straight margins, unarmed dorsally and with long simple setae along ventral margin; propodus about 5-5.5 times as long as wide, slightly curved, unarmed dorsally, with several 


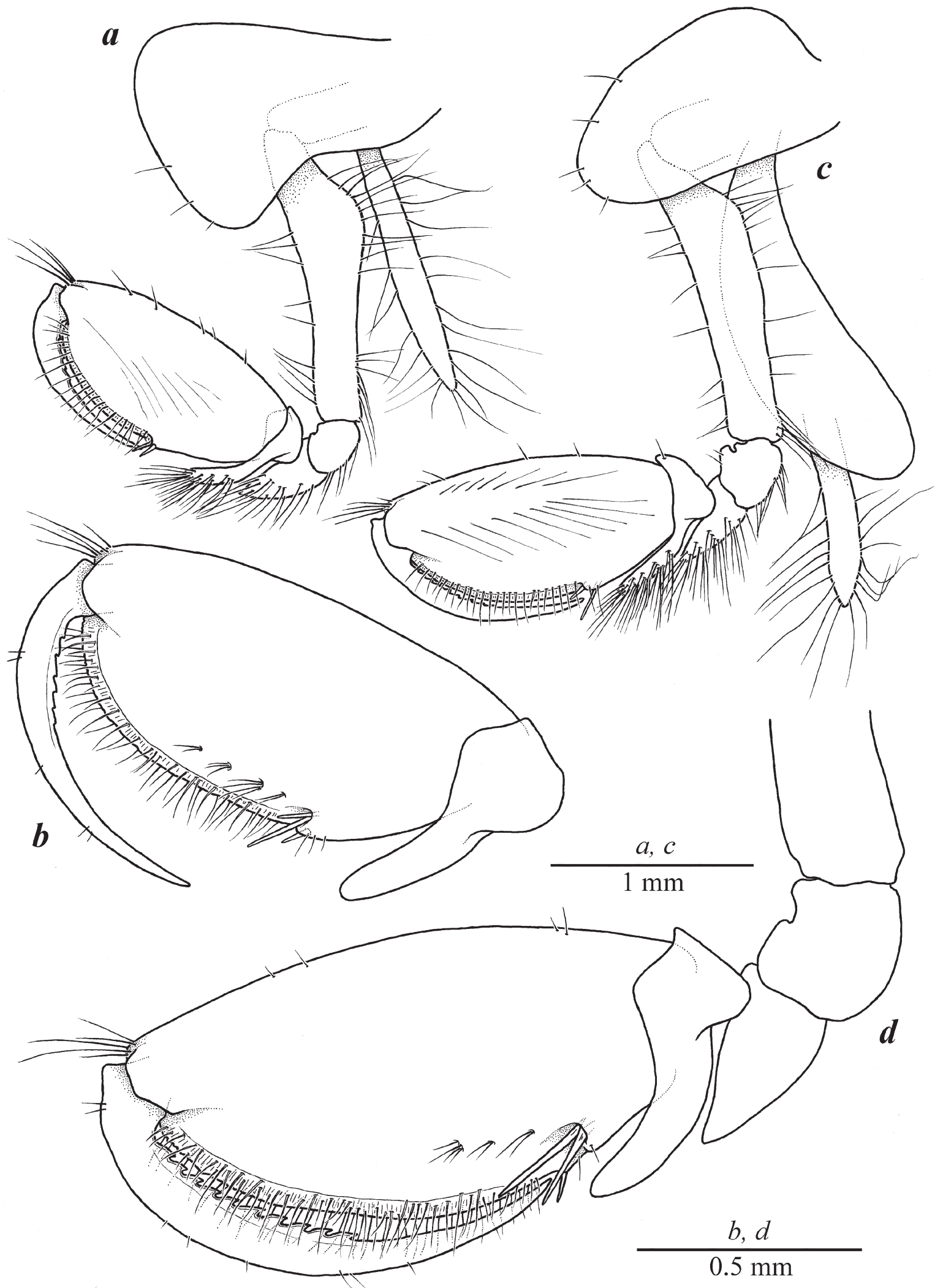

Fig. 3. Liljeborgia associata sp. nov., female (LEMMI) from Vostok Bay of the Sea of Japan. a. Gnathopod 1. b. Chela of Gn1. c. Gnathopod 2. d. Chela of Gn2. 
long simple setae at distodorsal angle, with 5 tiny spines along ventral margin; dactylus of normal length, slender, weakly curved, slightly shorter than propodus and slightly longer than carpus.

PeReIOPOD 5 (Fig. 4c). Coxa subquadrate, with medially concave ventral margin, unarmed; basis broad, with anterior and posterior border convex; anterior border with 12-13 small spines accompanied by small setae, posterior border with well-marked serration; ischium about as long as wide, with large simple spine on anterodistal corner; merus about 4 times as long as wide, with 4 short anterior spines, 1 large distodorsal spine paired with a spinule, and 1 simple distoventral spine; carpus about 4 times as long as wide, slightly shorter than merus, unarmed posteriorly, with 3 small anterior spines, and with a distal pair of spines anteriorly and posteriorly; propodus (Fig. 4d) about 6 times as long as proximal width, slightly tapering distally, with 10 anterior spines and series of long medial setae; dactylus distinctly curved and of normal stoutness, with tip entire, about $1 / 2$ of the length of propodus.

PeReIOPOD 6 (Fig. 4e). Coxa subquadrate, with medially concave ventral margin, unarmed; basis broad, with anterior and posterior border convex; anterior border with 10 small spines accompanied with small setae, posterior border with well-marked serration; ischium about as long as wide, with large simple spine on anterodistal corner; merus about 4 times as long as wide, with 5 short anterior spines, a pair of large distodorsal spines and 1 simple distoventral spine paired with a spinule; carpus about 4.5-5 times as long as wide, slightly shorter than merus, unarmed posteriorly, with 4 small anterior spines, and a distal pair of spines anteriorly and posteriorly; propodus (Fig. 4f) about 7 times as long as proximal width, tapering distally, with 4 long anterior spines and series of long medial setae; dactylus distinctly curved, sharp, about $1 / 3$ of the length of propodus.

Pereiopod 7 (Fig. 4g). Coxa almost rectangular; basis greatly broad, almost round, with convex anterior border and strongly convex posterior border; anterior border with 12 small conical spines, posterior border serrated, distal border with strong long spine; ischium about as long as wide, unarmed; merus broad, about 2.5-3 times as long as wide, with 4 anterior small spines and pair of anterodistal simple spines, 3 posterior spines and a pair of long posterodistal long spines; carpus about 5.5 times as long as wide, slightly longer than merus, with single or paired anterior spines and long simple setae posteriorly; propodus about 10 times as long as wide, tapering distally, with 4 small anterior spines and long setae posteriorly; dactylus straight, very long and slender, entire, about $1 / 3$ of the length of propodus.

Pleonite 1 (Fig. 5b). Posterodorsal area produced into 3 small teeth of which median is longest (Fig. 5e); Epl with normally developed posteroventral tooth, with posterior border weakly convex, covered with numerous simple setae.

Pleonite 2 (Fig. 5b). Posterodorsal area produced into 3 small teeth of which median is longest (Fig. 5e); Ep2 with normally developed posteroventral triangular tooth, with posterior border distinctly convex, covered with numerous simple setae.

Pleonite 3 (Fig. 5b). Posterodorsal area toothless (Fig. 5e); Ep3 with small posteroventral tooth and distinct rounded notch (Fig. $5 \mathrm{c}$ ), with posterior border convex.

URosomite 1. With well-developed dorsal lamina and posterodorsal tooth (Fig. 5d); peduncle of $U 1$ with medial distal corner rounded, with 4 dorsolateral spines of which proximal is longest, with 1 dorsomedial spine and 1 ventromedial spine; outer ramus with 5 small outer spines and 4 small medial spines; inner ramus with 4 small outer spines and 7 small medial spines.

UROSOMITE 2. With well-developed dorsal lamina and posterodorsal tooth (Fig. 5d); peduncle of $U 2$ with 4 slender dorsolateral distal spines, with 1 dorsomedial spine and 1 ventromedial spine; outer ramus 


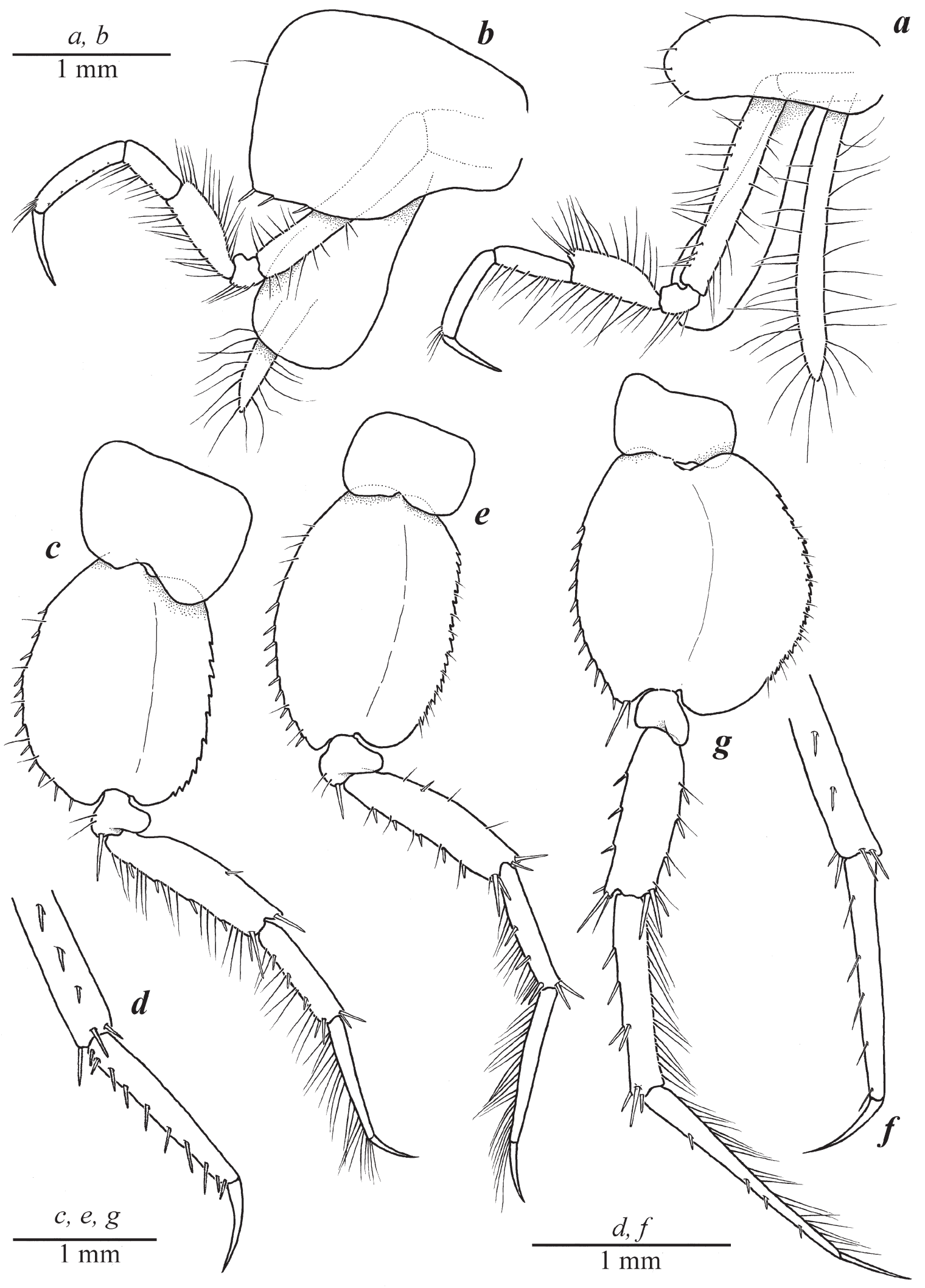

Fig. 4. Liljeborgia associata sp. nov., female (LEMMI) from Vostok Bay of the Sea of Japan. a. Pereopod 3. b. Pereopod 4. c. Pereopod 5. d. Distal segments of P5. e. Pereopod 6. f. Distal segments of P6. g. Pereopod 7. 


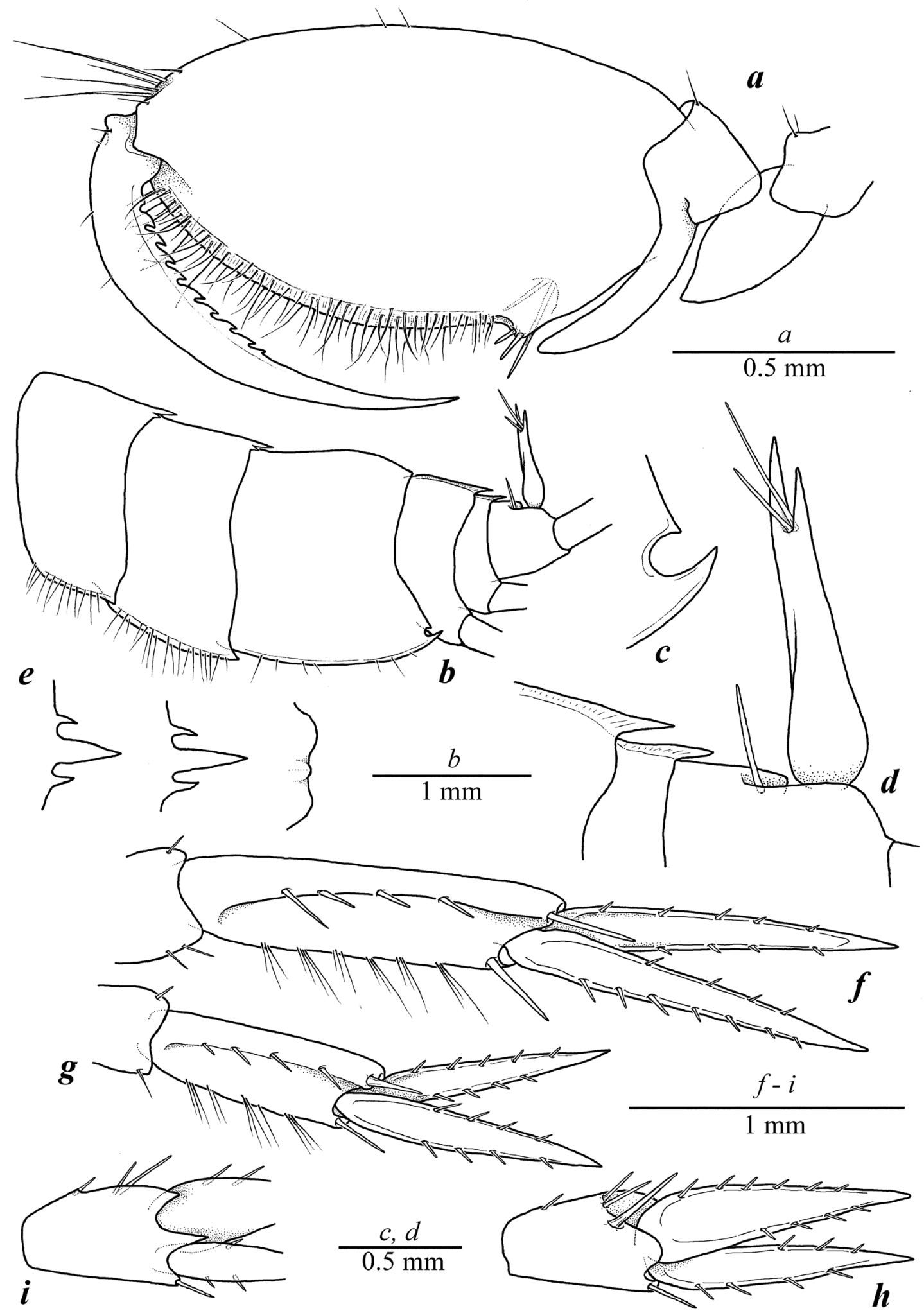

Fig. 5. Liljeborgia associata sp. nov., male (a) (LEMMI) and female (b-i) (LEMMI) from Vostok Bay of the Sea of Japan. a. Chela of Gn2. b. Pleonites 1-3 and urosomites 1-3. c. Ventroproximal margin of pleonite 3. d. Urosomites 1-3 and telson. e. Dorsoproximal margins of pleonites 1-3. f. Uropod 1. g. Uropod 2. h. Uropod 3. i. Peduncle of uropod 1, outer view. 
with 5 small outer spines and 4 small medial spines; inner ramus with 4 small outer spines and 4 small medial spines.

URosomite 3. With sharp medial projection (Fig. 5i), with 1-2 lateral spines, 1 long posterolateral tooth and 3 posterodorsal spines; outer ramus with 3-4 small outer spines and 4 small medial spines; inner ramus with 6 small outer spines and 4 small medial spines (Fig. 5h).

TeLson (Fig. 2k). With cleft reaching $0.85-0.9$ of telson length; distal teeth about $1 / 4$ of the length of telson, medial teeth longer than outer teeth, 2 interdental spines long and slender, overreaching outer teeth.

Coloration. General coloration of body and all appendages translucent white with large light and dark brown spots; some segments of appendages dark red or with dark red spots; eyes brightly white (Fig. 1).

BoDy SIZE. Largest collected female $=$ bl $6.5 \mathrm{~mm}$; largest collected male mostly similar in size to largest female, with bl $6.5 \mathrm{~mm}$.

\section{Taxonomic remarks}

The new species is distinctly morphologically similar to $L$. geminata and $L$. serratoides. At the same time, the new species can be clearly distinguished by several morphological features not known from the latter species.

From L. geminata (see description, presented by Barnard (1969)), the new species can be distinguished by the following characters: smaller dorsal crest on urosomites 1 and 2 (Fig. 5d); Mxl with wide, shovelshaped article 3 of palp (Fig. 2h); shorter and wider merus of $P 1$ and $P 2$ (see Fig. 4a-b); slender propodal segments of PP5-7 (see Fig. 4c-g); absence of long proximal seta of peduncle of $U 1$ (see Fig. 5f); shape of medial teeth of telson (Fig. $2 \mathrm{k}$ ), which are significantly longer and accompanied by 2 long interdental spines. At the same time, L. geminata seems to be more closely related to the new species by its very similar body coloration, the presence of a small dorsal crest on urosomites 1 and 2, short articles of peduncle of $A 1$, relatively stout distal segments of $P P 3-4$ (especially merus), and other morphological features that clearly separate both species from their relative $L$. serratoides.

From L. serratiodes (after Tzvetkova 1967), the new species is easily separated by the following characters: presence of a dorsal crest on urosomites 1 and 2; stout articles of peduncle of $A 1$ and $A 2$ (Fig. $2 \mathrm{~d}-\mathrm{e}$ ); wide distal article of palp of $M x 1$; stout and wider distal segments, especially merus, of $P P 1-2$; slender propodal segment of $P P 5-7$; length and shape of medial teeth of telson, which are significantly longer and accompanied by 2 long interdental spines. In addition, relatively stout and wide segments of PP3-4 are distinguishing features that separate the aforementioned species from tropical relatives, such as L. japonica and L. serrata (e.g., Nagata 1965; Azman \& Othman 2013).

From L. japonica and L. serrata, known from the Seto Inland Sea in southern Japan (see Nagata 1965), the new species can be distinguished by longer rostrum, mandibular palp with longer and slender articles, especially distal one; shorter and stouter articles of peduncle $A 1$ and $A 2$; stouter distal segments of $P P 3-4$, especially stout and wide merus of $P 3$; significantly shorted dactyli of $P P 5-7$; slender rami of $U 3$ and longer median teeth of telson.

From Liljeborgia hwanghaensis Kim \& Kim, 1990, known from the Korean coasts of the Yellow Sea $\left(37^{\circ} 23^{\prime} \mathrm{N}, 126^{\circ} 35^{\prime}\right.$ E) (see Kim \& Kim 1990), the new species can be clearly separated by the posterodorsal armature of pleonites 1 and 2 (3 teeth in the new species vs 5 teeth in L. hwanghaensis) and shorter median teeth of telson. 


\section{Habitat and ecology}

Specimens of Liljeborgia associata sp. nov. were collected inside the burrows of Urechis unicinctus (Drasche, 1880) (Polychaeta: Echiura: Urechidae), representing the first case of an association between liljeborgiid amphipods and spoon worms (Echiura). The spoon worm U. unicinctus lives in large U-shaped burrows constructed in muddy and sandy sediments in the inter- and subtidal zones in the Sea of Japan and the Yellow Sea (Abe et al. 2014; pers. obs.). About 20\% of the studied spoon worms burrows were inhabited by a single individual of the new species, which may indicate aggressive territorial behavior.

\section{Distribution}

The specimens of Liljeborgia associata sp. nov. were found in the southern part of the Peter the Great Bay and the northern part of Posjeta Bay in the Sea of Japan (Russian Federation) (see Fig. 1), where the present study was accomplished. The distribution of the new species is probably related with the distribution range of its host, U. unicinctus (see Abe et al. 2014).

Key to the species of the family Liljeborgiidae from the boreal waters of the NW Pacific (with species of Liljeborgia from the NE Pacific)

1. Gn1 significantly larger than Gn2; U3 large, paddle-like; postero-dorsal margin of pleonites 2-3 armed with marked teeth; eyes absent. NW Pacific: Sakhalin, the Sea of Okhotsk, depth 109$309 \mathrm{~m}$

Sextonia caecus Labay, 2017

- Gn1 similar to Gn2; U3 smaller than $U 1$ and $U 2$; postero-dorsal margin of pleonites 2-3 unarmed; eyes present (except $L$. cota)

2. Carpus of $G 1$ and $G 2$ with strongly produced slender ventral lobe extending along hind margin of propodus 3 (Liljeborgia Spence Bate, 1862)

- Carpus of G1 and G2 lacking produced ventral lobe. Known from the NE Pacific only Idunella G.O. Sars, 1894 (= Listriella J.L. Barnard, 1959)

3. Posterodorsal area of pleonites 1 and 2 produced into 5 teeth of which the median one is the longest. Known from the Korean coasts of the Yellow Sea .... Liljeborgia hwanghaensis Kim \& Kim, 1990

- Posterodorsal area of pleonites 1 and 2 produced into 3 teeth of which the median one is the longest

4. Telson cleft only $1 / 4$ to $1 / 3$, lacking terminal spines on lobes of telson; basis of PP5-7 more than twice as long as wide; blind. NE Pacific: from the Gulf of Alaska to the northern Baja California, depth 366-2000 m Liljeborgia cota Barnard, 1962

- Telson cleft nearly to base, lobes with imbedded terminal spine; basis of PP5-7 about 1-1.5 times as long as wide; with eyes

5. Epimeral plate 1 concave above postero-ventral tooth. From NE Atlantic to the coasts of Central California, depth 40-611 m Liljeborgia pallida Bate, 1857

- Epimeral plate 1 convex above postero-ventral tooth 6

6. Cusps of lobes of the telson longer medially than laterally; eyes reniform. NE Pacific: from Bahia de Los Angeles, Gulf of California, depth $46 \mathrm{~m}$ Liljeborgia marcinabrio Barnard, 1979

- Cusps of lobes of the telson subequal longer laterally than medially; eyes oval to subquadrate ..... 7

7. Urosomites 1-2 with well-marked dorsal crest, peduncle of $A 1$ with short and stout articles (article 3 about 1.5 times as long as wide; article 2 about as long as wide) 8 
- Urosomites 1-2 without dorsal crest, peduncle of $A 1$ with slender articles (article 3 about 2-2.5 times as long as wide; article 2 about 1.5 times as long as wide). NW Pacific: Posjeta Bay in the Sea of Japan, intertidal

Liljeborgia serratoides Tzvetkova, 1967

8. Medial teeth of telson about 0.15 length of telson, less than 1.5 times longer than outer teeth and accompanied by 1 long interdental spine. NE Pacific: from Goleta to the northern Baja California, depth 3-70 m

Liljeborgia geminata Barnard, 1969

- Medial teeth of telson about 0.25 length of telson, about 2 times longer than outer teeth and accompanied by 2 long interdental spines. NW Pacific: the Peter the Great Bay and the northern part of Posjeta Bay in the Sea of Japan, intertidal

Liljeborgia associata sp. nov.

Some other species of the genus Liljeborgia are known from the region and the Sea of Japan (e.g., Ishimaru 1994; Ren 2007). For example, Ishimaru (1994) notes Liljeborgia aequabilis Stebbing, 1888 from the tropical part of the Seto Inland Sea influenced by the Kuroshio Current. This species is actually recognized in Australia, New Zealand and the Sulu Sea as a common associate of hermit crabs (Stebbing 1888; after Hurley 1954; see also Vader 1995) and by most morphological features, especially long and slender segments of PP3-4 and the form of telson (see above), belong to the tropical representatives of the genus, such as L. japonica and L. serrata, or possibly represent an undescribed species. These species are known from warm (tropical) waters and probably are not present in the boreal zone of the northern Pacific Ocean.

\section{Discussion}

The symbiotic communities associated with deep-burrowing invertebrates are very diverse and still include many undescribed species. Burrows of spoon worms of the genus Urechis as well as almost all large echiuroid worms are inhabited by various symbiotic animals, such as shrimps, crabs, bivalves and even fishes (e.g., Fisher \& MacGinitie 1928; Anker et al. 2005, 2015; Itani et al. 2005; Goto \& Kato 2012; Marin 2014; Goto et al. 2017). The symbiotic fauna associated with U. unicinctus in the Peter the Great Bay has not yet been fully studied, whereas the discovered symbiotic assemblage includes unidentified acoela turbellarian worms (Platyhelminthes: Rhabditophora: Polycladida), crabs Pinnixa rathbuni Sakai, 1934 (Crustacea: Decapoda: Pinnotheridae) and Sestrostoma balssi (Shen, 1932) (Crustacea: Decapoda: Varunidae), copepod Goidelia cf. japonica Embleton, 1901 (Crustacea: Copepoda: Poecilostomatoida: Catiniidae) and goby Gymnogobius heptacanthus (Hilgendorf, 1879) (Pisces: Gobiidae) (pers. obs.). Liljeborgia associata sp. nov. is probably only associated with the burrows of the spoon worms, since no free-living specimens of the genus Liljeborgia or any other liljeborgiid amphipods were sampled on the surface of muddy or sand-bottom substrates in the Peter the Great Bay and Posjeta Bay in the Sea of Japan during the present or previous studies (e.g., Gurjanova 1951; Tzvetkova 1967). Moreover, Tzvetkova (1967) described a quite common L. serratoides from mussel communities, overgrowing rocks and hard substrates in Posjeta Bay of the Sea of Japan, while Liljeborgia species were not recorded on muddy and soft-bottom substrates that dominate the bay. This fact indirectly proves that Liljeborgia associata sp. nov. rarely emerges from the host's burrows and does not inhabit the surrounding softbottom substrates as a free-living species.

At the same time, representatives of the family Liljeborgiidae have been observed in association with other marine invertebrates. Often Liljeborgia spp. are observed is association with hermit crabs (Taylor 1979; Vader 1995). Liljeborgia aequabilis Stebbing, 1888, associated with the hermit crab Dardanus arrosor (Herbst, 1796) (Crustacea: Decapoda: Diogenidae), has a specific colorful body coloration (e.g., Vader \& Tandberg 2015: fig. 4; Taylor 1979: fig. 1), similar to other symbiotic species of the family (Barnard 1959; Mills 1962: fig. 2), while none of the free-living species are known to have bright pigmentation in life (e.g., d'Udekem d'Acoz \& Vader 2009; d'Udekem d'Acoz 2010; Cadien 2015). Liljeborgia psaltrica Krapp-Schickel, 1975 is recorded among associates of the orange coral 
Astroides calycularis (Pallas, 1766) (Cnidaria: Scleractinia: Dendrophylliidae) in the Mediterranean (Terrón-Siglera et al. 2016). Idunella clymenellae (Mills, 1962) was found and described inside the tube arrays of the polychaete worm Clymenella torquata (Leidy, 1855) (Polychaeta: Maldanidae) in the intertidal flats of Barnstable Harbor, Massachusetts (Mills 1962; Sanders et al. 1962). These amphipods inhabit about $20-25 \%$ of tubes with live polychaetes (Mills 1962) and show a positive response to polychaetes mucus (Batcheler \& Mills 1965). Also, Idunella albina (J.L. Barnard, 1959) was commonly collected from dense beds of echiuroid worms off Californian coasts (Barnard 1959), however, the direct relationship of this species with spoon worms is not shown. An undescribed species of the genus Idunella is reported from the burrows of the mud shrimp Upogebia affinis (Say, 1818) (Crustacea: Decapoda: Upogebiidae) (Fox \& Bynum 1975), while individuals of the genus Idunella (= Listriella) are common inhabitants of maldanid and terebellid polychaete tubes (Barnard 1969; Bousfield 1973) and are reported with holothurians (Fox \& Bynum 1975; Vader 1978). It is probable that associations of these animals with marine invertebrates are much more common than is currently known.

As mentioned above, according to morphological data, the new species is closely related to L. geminata. Unfortunately, minimal genetic data on the family Liljeborgiidae are presented in GenBank (NCBI) database, and genetic data are not available for the relative congeners of the described species. At the same time, it can be assumed that Liljeborgia associata sp. nov. and L. geminata represent a pair of closely related vicariant taxa known as boreal amphi-Pacific species. Such species had a wide distribution area in the northern part of the Pacific Ocean during the Pliocene-Middle Pleistocene period, characterized by a higher water temperature and sea level, which allowed the boreal fauna to move from east to west and even through the Arctic basin [as Great Trans-Arctic Biotic Interchange (GTAI)] (Einarsson et al. 1967; Durham \& MacNeil 1967; Briggs 2003). During the temperature decreasing in the Sea of Okhotsk and the Bering Sea in the Late Pleistocene (about $2 \mathrm{Ma}$ ago), the ranges were subsequently divided into the western and the eastern distribution ranges (Zenkevitch 1963; Briggs 2003; Maggs et al. 2008; Marin 2018a). Further genetic data will allow a more detailed description of the phylogenetic relationships within the representatives of the family from the northern part of the Pacific Ocean.

\section{Acknowledgements}

The author is very grateful to the staff of the biological scientific station "Vostok" of NSCMB FEB RAS (Vladivostok, Russia) and personally K. Dudka and Dr A. Mayorova for their help during the field sampling. The study was financially supported by the Russian Foundation for Basic Research (RFBR) (grant 18-04-01093_A "Large burrowing crustaceans (Callianassidae and Upogebiidae) and their symbionts: diversity and trophic interaction") and the Russian Scientific Foundation (RSF) (grant 19-74-10104).

\section{References}

Abe H., Sato-Okoshi W., Tanaka M., Okoshi K., Teramoto W., Kondoh T., Nishitani G. \& Endo Y. 2014. Swimming behavior of the spoon worm Urechis unicinctus (Annelida, Echiura). Zoology 117 (3): 216-223. https://doi.org/10.1016/j.zool.2013.12.001

Anker A., Murina G.V., Lira C., Vera Caripe J.A., Palmer A.R. \& Jeng M.S. 2005. Macrofauna associated with echiuran burrows: a review with new observations of the innkeeper worm, Ochetostoma erythrogrammon Leuckart and Rüppel, in Venezuela. Zoological Studies 44: 157-190.

Anker A., Komai T. \& Marin I. 2015. A new echiuran-associated snapping shrimp (Crustacea: Decapoda: Alpheidae) from the Indo-West Pacific. Zootaxa 3914 (4): 441-455.

https://doi.org/10.11646/zootaxa.3914.4.4 
Azman B.A.R. \& Othman B.H.R. 2013. Shallow water marine gammaridean amphipods of Pulau Tioman, Malaysia, with the description of a new species. ZooKeys 335: 1-31. https://doi.org/10.3897/zookeys.335.5567

Barnard J.L. 1959. Liljeborgiid amphipods of Southern California coastal bottoms, with a revision of the family. Pacific Naturalist 1 (3-4): 12-28.

Barnard, J.L. 1969. Gammaridean Amphipoda of the rocky intertidal of California: Monterey Bay to La Jolla. Bulletin of the United States National Museum 258: 1-230.

https://doi.org/10.5479/si.03629236.258.1

Barnard J.L. \& Karaman G.S. 1991. The families and genera of marine gammaridean Amphipoda (except marine gammaroids). Part 1. Records of the Australian Museum 13 (Supplement): 1-417. https://doi.org/10.3853/j.0812-7387.13.1991.91

Batcheller R. \& Mills E.L. 1965. Behavoral studies on the commensal amphipod crustacean, Listriella clymenellae Mills. Biological Bulletin 129 (2): 398.

Bousfield E.L. 1973. Shallow-water Gammaridean Amphipoda of New England. Comstock Publishing Associates/Cornell University Press, Ithaca, New York.

Briggs J.C. 2003. Marine centers of origin as evolutionary engines. Journal of Biogeography 30: 1-18. https://doi.org/10.1046/j.1365-2699.2003.00810.x

Cadien D.B. 2015. Amphipoda of the Northeast Pacific (Equator to Aleutians, intertidal to abyss): XXVIII. Ampeliscoidea - an updated review. Southern California Association of Marine Invertebrate Taxonomists (SCAMIT). Available from Amphipoda of the Northeast Pacific. Ampeliscoidea [accessed 20 Feb. 2020].

Durham J.W. \& MacNeil F. 1967. Cenozoic migrations of marine invertebrates through the Bering Strait region. In: Hopkins D.M. (ed.) The Bering Land Bridge: 326-349. Stanford University Press, Stanford.

d'Udekem d'Acoz C. 2010. Contribution to the knowledge of European Liljeborgiidae (Crustacea, Amphipoda), with considerations on the family and its affinities. Bulletin de l'Institut royal des Sciences Naturelles de Belgique, Biologie / Bulletin van het Koninklijk Belgisch Instituut voor Natuurwetenschappen, Biologie 80: 127-259.

d'Udekem d'Acoz C. \& Vader W. 2009. On Liljeborgia fissicornis (M. Sars, 1858) and three related new species from Scandinavia, with a hypothesis on the origin of the group fissicornis. Journal of Natural History 43 (33-34): 2087-2139. https://doi.org/10.1080/00222930903094647

Einarsson T., Hopkins D.M. \& Doel R.D. 1967. The stratigraphy of Tjörnes, northern Iceland, and the history of the Bering Land Bridge. In: Hopkins D.M. (ed.) The Bering Land Bridge: 312-325. Stanford University Press, Stanford.

Eleftheriou A. \& Mcintyre A. 2005. Methods for Study of Marine Benthos. $3^{\text {rd }}$ Ed. Vol. 1004. Blackwell Science, Hoboken, NJ. https://doi.org/10.1002/9780470995129

Fisher W.K. \& MacGinitie G.E. 1928. The natural history of an echiuroid worm. Annals and Magazine of Natural History 1: 204-213. https://doi.org/10.1080/00222932808672765

Fox R.S. \& Bynum K.H. 1975. The amphipod crustaceans of North Carolina estuarine waters. Chesapeake Science 16: 223-237. https://doi.org/10.2307/1350941

Goto R. \& Kato M. 2012. Geographic mosaic of mutually exclusive dominance of obligate commensals in symbiotic communities associated with a burrowing echiuran worm. Marine Biology 159: 319330. https://doi.org/10.1007/s00227-011-1810-8 
Goto R., Hamamura Y. \& Kato M. 2017. Morphological and ecological adaptation of Basterotia bivalves (Galeommatoidea: Sportellidae) to symbiotic association with burrowing echiuran worms. Zoological Science 28 (3): 225-234. https://doi.org/10.2108/zsj.28.225

Gurjanova E.F. 1951. Amphipods of the seas of the USSR and surrounding waters (AmphipodaGammaridea). Opredeliteli po faune SSSR 41: 1-1029. [in Russian.]

Hurley D.E. 1954. Studies on the New Zealand amphipodan fauna. 9. The families Acanthonotozomatidae, Pardaliscidae and Liljeborgiidae. Transactions of the Royal Society of New Zealand 32: 763-802.

Ishimaru S. 1994. A catalogue of gammaridean and ingolfiellidean Amphipoda recorded from the vicinity of Japan. Report of the Sado Marine Biological Station, Niigata University 24: 29-86.

Itani G., Izichi M. \& Ueda H. 2005. Crab species collected from the burrows of Urechis unicinctus in Hiuchi-nada, the central Seto Inland Sea, Japan. Cancer 14: 1-4. [In Japanese.] https://doi.org/10.18988/cancer.14.0_1

Kim C.B. \& Kim W. 1990. A new species of the genus Liljeborgia (Crustacea, Amphipoda, Liljeborgiidae) from Korea. Korean Journal of Zoology 33: 396-401.

Labay V.S. 2017. A new species of Sextonia Chevreux, 1920 (Crustacea: Amphipoda: Liljeborgiidae) from the Okhotsk Sea. Zootaxa 4353 (3): 506. https://doi.org/10.11646/zootaxa.4353.3.6

Maggs C.A., Castilho R., Foltz D., Henzler C., Jolly M.T., Kelly J., Olsen J., Perez K.E., Stam W., Väinölä R., Viard F. \& Wares J. 2008. Evaluating signatures of glacial refugia for North Atlantic benthic marine taxa. Ecology 89: 108-122. https://doi.org/10.1890/08-0257.1

Marin I. 2010. Re-description of rare alpheid shrimp Betaeus levifrons Vinogradov, 1950 (Crustacea, Decapoda, Alpheidae) from the Peter the Great Bay, the Russian coast of the Sea of Japan. Zootaxa 2613: 51-60. https://doi.org/10.11646/zootaxa.2613.1.5

Marin I.N. 2013. A new species of callianassid ghost shrimp of the genus Nihonotrypaea Manning \& Tamaki, 1998 (Crustacea, Decapoda, Axiidea, Callianassidae) from southern part of the Russian coast of the Sea of Japan. Zootaxa 3694 (5): 434-444. https://doi.org/10.11646/zootaxa.3694.5.2

Marin I. 2014. The first record of an association between a pontoniine shrimp (Crustacea: Decapoda: Palaemonidae: Pontoniinae) and a thalassematid spoon worm (Echiura: Thalassematidae), with the description of a new shrimp species. Zootaxa 3847 (4): 557-566.

https://doi.org/10.11646/zootaxa.3847.4.5

Marin I.N. 2015. Complete morphological re-description of mud-dwelling axiid Leonardsaxius amurensis (Kobjakova, 1937) with remarks on Axiidae (Crustacea: Decapoda: Axiidea) from the Russian coast of the Sea of Japan. Zootaxa 3937 (3): 549-563. https://doi.org/10.11646/zootaxa.3937.3.7

Marin I.N. 2016. The species composition and ecological features of pea crabs of the genus Pinnixa White, 1846 (Brachyura: Pinnotheridae) in Peter the Great Bay, the Sea of Japan. Russian Journal of Marine Biology 42 (2): 139-145. https://doi.org/10.1134/S1063074016020061

Marin I. 2017. Athanas alpheusophilus sp. nov. (Decapoda: Alpheidae) - a new Alpheus-associated shrimp from the Russian coast of the Sea of Japan. Zootaxa 4324 (12): 50-62.

https://doi.org/10.11646/zootaxa.4324.1.3

Marin I. 2018a. Deep water decapod crustaceans (Crustacea: Decapoda) collected by SokhoBio 2015 Expedition from bathyal and abyssal waters of the Sea of Okhotsk and adjacent NW Pacific with the re-description of Calocarides okhotskensis Sakai, 2011 (Axiidae). Deep Sea Research Part II: Topical Studies in Oceanography 154: 330-341. https://doi.org/10.1016/j.dsr2.2018.04.007 
Marin I. 2018b. New records of holothurian-associated pea crab Pinnixa tumida Stimpson, 1858 (Crustacea: Decapoda: Pinnotheridae) from the Russian coastal waters of the Sea of Japan. Ukrainian Journal of Ecology 8 (4): 307-310.

Marin I.N. \& Kornienko E.S. 2014 The list of Decapoda species from Vostok Bay Sea of Japan. Biodiversity and Environment of Far East Reserves 2: 50-72.

Marin I.N., Korn O.M. \& Kornienko E.S. 2011. Symbiotic crab Sestrostoma balssi (Shen, 1932) (Varunidae: Gaeticinae) from Vostok Bay, Sea of Japan: a new species for the fauna of Russia. Russian Journal of Marine Biology 37 (6): 509-511. https://doi.org/10.1134/S1063074011060113

Marin I.N., Korn O.M. \& Kornienko E.S. 2013 Upogebia yokoyai Makarov, 1938 (Decapoda: Gebiidea: Upogebiidae) - a new species of gebiid shrimps for fauna of the Sea of Japan. Biologiya Morya 39 (3): 221-226. [in Russian.]

Mills E.L. 1962. A new species of liljeborgiid amphipod, with notes on its biology. Crustaceana 4 (2): 158-162. https://doi.org/10.1163/156854062X00201

Nagata K. 1965. Studies on marine gammaridean amphipoda of the Seto Inland Sea. I. Publications of the Seto Marine Biological Laboratory 13 (2): 131-170.

Ren X.Q. 1992. Studies on the Gammaridea (Crustacea: Amphipoda) from Jiaozhou Bay (Yellow Sea). Transactions of the Chinese Crustacean Society 3: 214-317. [In Chinese, with English descriptions for new species.]

Ren X.Q. 2007. Suborder Gammaridea Dana, 1852. In: Liu R.Y. (ed.) Checklist of Marine Biota of China Seas: 672-687. Science Press, Beijing.

Sanders H.L., Goudsmit E.M., Mills E.L. \& Hampson G.E. 1962. A study of the intertidal fauna of Barnstable Harbor, Massachusetts. Limnology and Oceanography 7: 63-79.

https://doi.org/10.4319/1o.1962.7.1.0063

Stebbing T.R.R. 1888. Report on the Amphipoda collected by H.M.S. Challenger during the years $1873-$ 1876. Report on the Scientific Results of the Voyage of H.M.S. Challenger during the years 1873-76. Zoology 29: 1-1737. https://doi.org/10.5962/bhl.title.6513

Taylor P.R. 1979. An association between an amphipod, Liljeborgia sp., and the hermit crab, Pagurus hemphilli (Benedict). Marine Behaviour and Physiology 6: 185-188.

https://doi.org/10.1080/10236247909378565

Temereva E.N. \& Chichvarkhin A. 2017. A new phoronid species, Phoronis embryolabi, with a novel type of development, and consideration of phoronid taxonomy and DNA barcoding. Invertebrate Systematics 31 (1): 65-84. https://doi.org/10.1071/IS16032

Terrón-Siglera A., León-Muez D., Peñalver-Duque P. \& Espinosa Torre F., 2016. Diets of peracarid crustaceans associated with the orange coral Astroides calycularis in southern Spain. Mediterranean Marine Science 17 (1): 170-173. https://doi.org/10.12681/mms.1298

Tzvetkova N.L. 1967. [On the fauna and ecology of amphipods (Amphipoda, Gammaridea) of Posjeta Bay (the Sea of Japan)]. Issledovanija Fauny Morej 5 (13): 160-195. [in Russian.]

Vader W. 1978. Associations between amphipods and echinoderms. Astarte 11: 123-134.

Vader W. 1995. Liljeborgia species (Amphipoda, Liljeborgiidae) as associates of hermit crabs. Polskie Archiwum Hydrobiologii 42 (4): 517-525.

Vader W. \& Tandberg A.H.S. 2015. Amphipods as associates of other Crustacea: a survey. Journal of Crustacean Biology 35 (4): 522-532. https://doi.org/10.1163/1937240X-00002343 
Zenkevitch L. 1965. Biology of the Seas of the U.S.S.R. George Allen \& Unwin Ltd., London. https://doi.org/10.1002/iroh.19650500115

Manuscript received: 22 September 2019

Manuscript accepted: 3 December 2019

Published on: 11 March 2020

Topic editor: Rudy Jocqué

Desk editor: Pepe Fernández

Printed versions of all papers are also deposited in the libraries of the institutes that are members of the EJT consortium: Muséum national d'histoire naturelle, Paris, France; Meise Botanic Garden, Belgium; Royal Museum for Central Africa, Tervuren, Belgium; Royal Belgian Institute of Natural Sciences, Brussels, Belgium; Natural History Museum of Denmark, Copenhagen, Denmark; Naturalis Biodiversity Center, Leiden, the Netherlands; Museo Nacional de Ciencias Naturales-CSIC, Madrid, Spain; Real Jardín Botánico de Madrid CSIC, Spain; Zoological Research Museum Alexander Koenig, Bonn, Germany; National Museum, Prague, Czech Republic. 